\title{
Pioglitazonun Metabolik Sendromlu Sıçan Kalp Fonksiyonuna Etkisinin Elektrofizyolojik Yöntemlerle İncelenmesi*
}

\author{
An Investigation on Effects of Pioglitazone in the Heart Function from Rats with Metabolic Syndrome by Using \\ Electrophysiological Techniques
}

Ayșegül Toy¹, Makbule Fulya Tutar¹, Yusuf Olgar¹, Esma Nur Okatan¹, Sinan Değirmenci , Seyfullay Aksu², İsmet Aydın², Emrullah Bıçakçı², Muhammet Doğan², Ahmet Gündüz², Erkan Tuncay ${ }^{1}$, Belma Turan ${ }^{1}$

'Ankara Üniversitesi, Tip Fakültesi, Biyofizik Anabilim Dalı.
2Ankara Üniversitesi, Tıp Fakültesi, Dönem III Öğrencileri.
*Bu çalssmanın finansal desteği, TÜBiTAK SBAG-1135466 no'lu projeden
sağlanmıștır.
Geliș tarihi: $25.06 .2015 \bullet$ Kabul tarihi: 10.08.2015

iletișim

Prof. Dr. Belma Turan

Ankara Üniversitesi Tıp Fakültesi

Biyofizik Anabilim Dalı

e-posta: belma.turan@medicine.ankara.edu.tr

Tel: +903125958186
Amaç: Metabolik sendrom (MetS), genellikle insülin-direnci ile karakterize, kardiyovasküler sistem sorunlarıyla seyreden, mekanizması henüz tam olarak anlașılamamıș bir hastalıktır. Diğer yandan, MetS-indüklü komplikasyonların tedavisinde kullanılan bazı ilaçların, kardiyovasküler sistem sorunlarına ek sorunlar getirebildiği tartısılmaktadır. Bu çalıșmada, ilk olarak insülin-duyarlaștırıcı olarak bilinen pioglitazonun, MetSindüklü bozulan kalp fonksiyonu üzerindeki etkisini incelemeyi hedefledik. İkinci olarak, MetS-indüklü etkinin artan oksidatif stres üzerinden olup olmadığını göstermek amacıyla, bilinen bir antioksidan (kuersetin) uygulayarak sonuçları karșılaștırmalı olarak incelenmesi hedefledik.

Materyal ve Metodlar: Toplam 28-adet erkek Wistar-türü sıçanlar (3 aylık), kontrol grubu (Kon), MetS grubu (MetS; 18-hafta içme suyuna \%32 sükroz eklenerek olușturulmuștur), MetS-grubunun 16. haftasından itibaren 2-hafta süre ile ya pioglitazon uygulanmıs MetS-grubu (Piog; $30 \mathrm{mg} / \mathrm{kg} / \mathrm{gün}$ ), ya da kuersetin uygulanmıs MetS grubu (Kuer; $75 \mathrm{mg} / \mathrm{kg} /$ gün) olarak düzenlenmiștir. Tüm hayvanlar standart koșullarda normal sıçan yemi ile beslenmiștir. Çalıșma sonunda, hayvanların vücut ağırlıkları, kan șekeri ile serum toplam oksiSıçan yemi ile beslenmiștir. Çalıșma sonunda, hayvanların vücut ağırlıkları, kan șekeri ile serum toplam oksi-
tatif stres (TOS) ve antioksidan (TAS) durumları özel kit ile ölçülmüștür. Langendorff-izole-organ-sisteminde sol ventrikül içi basınç değișimleri (SVBD) ile, enzimatik yöntemle kalbin ventrikülünden izole edilen kardiyomiyositlerde $\left(\mathrm{Ca}^{2+}\right.$-duyarlı florofor Fura-2AM ile boyanmıș) hücre-içi bazal serbest- $\mathrm{Ca}^{2+}$ seviyesi $\left(\left[\mathrm{Ca}^{2+}\right]_{i}\right)$ ve elektriksel-uyarı altında (aksiyon-potansiyeli sırasında) geçici $\left[\mathrm{Ca}^{2+}\right]_{i}$ değișimleri incelenmiștir.

Bulgular ve Sonuç: Pioglitazon veya kuersetin, MetS-grubunda kilo artıșı ve yüksek kan șekeri üzerinde pozitif etkiler gösterirken, her iki ajan artmıs olan serum TOS seviyelerini değiștirememiș, buna karșılık küçük fakat anlamlı seviyede TAS seviyesinin yükșelmesine neden olmuslardır $(p<0,05)$. Kuersetin, MetS-grubunda baskılanmıș olan SVBD'leri etkilemezken, pioglitazon daha da baskılanmasına neden olmuștur. Buna karșılık, MetS-grubunda, artmıș olan bazal $\left[\mathrm{Ca}^{2+}\right]_{i}$ seviyesi ile elektriksel uyarı altında ölçülen geçici $\left[\mathrm{Ca}^{2+}\right]_{i}$ değișimlerinin her iki ajan uygulaması ile normal seviyelere döndüğü görülmüștür. Her iki uygulamanın hücre düzeyinde özellikle $\left[\mathrm{Ca}^{2+}\right]_{i}$ değișimlerini benzer șekilde pozitif yönde etkilerken, organ düzeyinde aynı pozitif etkilerin gözlenememesinin nedeni, bu 2 ajanın MetS-indüklü kalp dokusunda gelișen fibröz olușumu üzerinde etkili olamamalarından kaynaklanabileceğini düșündürmektedir.

Anahtar sözcükler: Diyabet, Antioksidanlar, Oksidatif Stres, İnsülin-Direnci, Kasılma Kuvveti, $\mathrm{Ca}^{2+}$ Homeostazı.

Objective: Metabolic syndrome (MetS), generally characterized with insulin-resistance, leads to

severe cardiovascular disorders, however, the underlying mechanisms of this syndrome has not yet been fully determined. In addition, there are some controversies related with unti-diabetic agents used for treatment of MetS-induced complications, including their aggravating effects on the depressed cardiac function. Therefore, in this study, we first aimed to investigate the effects of pioglitazone, known as a insulinsensitizer, on MetS-induced heart dysfunction. Second, for a comparative study to determine whether MetS-induced heart dysfunction is due to increased oxidative stress, we used a known antioxidant (quercetin) to MetS rats for the same period.

Material and Methods: Total 28 male Wistar rats ( 3 months) were grouped as control group, (Con), MetS group (MetS; added 32\% sucrose to drinking water for 18-week), MetS group supplemented with pioglitazone (Piog; $30 \mathrm{mg} / \mathrm{kg} /$ day via gavage for 2 -week, from $16^{\text {th }}$-week of MetS-group) and MetS with quercetin zone (Piog; $30 \mathrm{mg} / \mathrm{kg} /$ day via gavage for 2 -week, from $16^{\text {th }}$-week of MetS-group) and MetS with quercetin
(Quer; $75 \mathrm{mg} / \mathrm{kg} /$ day via gavage for 2-weeks from $16^{\text {th }}$-week of MetS group). All rats were fed with standard rat-diet and tap water at standard condition. At the end of experimental period, the body weights and blood glucose levels, and total oxidative status (TOS) and total antioxidant status (TAS) in serum by using special kits were measured for all animals. By using Langendorff-isolated-organ system, left ventricle pressure changes (LVPC) were measured in isolated hearts. The basal level of intracellular free $\mathrm{Ca}^{2+}\left(\left[\mathrm{Ca}^{2+}\right]_{i}\right)$ and $\mathrm{Ca}^{2+}$ transients under electrical-situmulation (under action-potential) were measured in freshly isolated cardiomyocytes by enzymatic-method (loaded with $\mathrm{Ca}^{2+}$-sensitive fluorescence dye, Fura-2AM).

Results and Discussion: Either pioglitazone or quercetin application have positive effects on body weight and high blood sugar levels in MetS-group rats. Additionally, both agents caused a small but significant increase on serum TAS levels $(p<0.05)$ while they could not affect the increased serum TOS levels, significantly. Furthermore, quercetin has no significant effect on depressed LVPC levels, while pioglitazone treatment caused even more depression on LVPC levels $(p<0.05)$. Nonetheless, both treatments induced significant protection against MetS-induced alterations in calculated parameters of $\left[\mathrm{Ca}^{2+}\right]_{i}$ levels and the $\mathrm{Ca}^{2+}$ transients obtained under electrical stimulation $(p<0.05)$. Under the light of our data, such as positive effects on cellular level including parameters of $\left[\mathrm{Ca}^{2+}\right]_{i}$ changes in isolated cardiomyocytes and no similar positive effects in isolated-organ level, we can assert that these two-agents may have no effects on MetS-induced marked generation of fibrosis in the heart with high sucrose diet in rats.

Key Words: Diabetes, Antioxidants, Oxidative Stress, Insulin-Resistance, Tension, $\mathrm{Ca}^{2+}$ - Homeostasis.. 
Metabolik sendrom (MetS), obezite, hiperinsülinemi, hiperlipidemi ve hipertansiyon ile karakterize, çoğunlukla kardiyovasküler bozukluklar ve insülin direncinin gelişmesine bağlı tip 2 diyabet için ciddi risk faktörü oluşturabilen önemli bir patolojidir $(1,2)$. Diğer yandan, fiziksel aktivite eksikliği, dengesiz ve aşırı beslenme gibi başlıca nedenler bireylerde insülin direncine yol açarak MetS oluşumuna zemin hazırlayabilmektedir (3). Toplumlardaki görülme sıklığı gün geçtikçe artan MetS'un ülkemizdeki prevalans1, erkeklerde \% 24-32, kadınlarda \% 39-45 oranindadir (4-8). Deney hayvanlarında MetS genellikle genetik manipülasyon ya da diyetindüklü olarak oluşturulmaktadır. Fruktozun diyet kaynağ1 olan sükroz ile besleme, deney hayvanlarında insanda oluşan MetS'a en yakın patolojilerin gözlendiği MetS deney modelidir. Sükroz, bozulmuş glukoz toleransiyla beraber plazmada artmış insülin, leptin, trigliserit, glukoz ve yağ asitleri ile MetS oluşumuna yol açmaktadır (9). Diğer yandan, yüksek karbonhidratyüksek yağ içeren diyet insan diyetine en yakin diyet modellerden biri olarak gösterilse de, gözlenen patolojilerin mekanistik açıklamalarının yapilması hedeflenen araştırmalar için, diyet heterojenitesi dezavantaj oluşturduğundan bu yolla MetS daha az tercih edilen bir modeldir (9).

Literatür verileri, 3-4 haftalık yüksek sükroz alımının deney hayvanlarında plazma glukoz düzeylerini etkilemezken hiperinsülinemiye neden olduğu, plazma trigliserit ve LDL kolesterol düzeylerinin yükseldiği ve sistemik lipid regülasyonunun bozulduğunu göstermektedir (1017). Ayrica bu diyetin hem dişi ve hem de erkek siçanlarda hipertansiyona neden olduğu rapor edilmiştir (12, 14, 18, 19). Özet olarak, MetS ile ilişkili kalp fonksiyon bozuklugunun altında yatan nedenler arasinda, dislipidemi, insülin direnci ve hiperglisemi kardiyomiyosit metabolizmasinda bozukluk gibi patolojik süreçlerin bulunduğu ve bunla- rin son etki olarak kalp fonksiyon bozukluğu ya da kalp yetmezliği gelişimine neden olduğu anlaşılmaktadır (20). Kalp yetmezliği durumunda bozulmuş hücre içi $\mathrm{Ca}^{2+}$ homeostazının kalp performansinı etkilediği de bilinen temel mekanizmalardan biridir.

Diğer yandan, MetS'da kalp fonksiyon bozukluğunun altında yatan mekanizmalar arasinda temel olarak mitokondri fonksiyon bozukluğu ile artan oksidatif stres (ve/veya azalan antioksidan savunma mekanizmas1) gibi faktörlerin bulunduğu da ileri sürülmektedir (20). Reaktif oksijen ve nitrojen türlerinin (ROS ve RNS) mitokondri ve ekstramitokondriyal kaynakları ile azalmış antioksidan savunma sistemi mekanizmalar1 MetS'lu insan ve hayvanların miyokardiyumunu karakterize eder (21-24). MetS-indüklü komplikasyonların tedavisinde, sıklıkla anti-diyabetik ilaçlar kullanılmasına karșın bazı durumlarda antioksidanlar da tavsiye edilmektedir. Diğer yandan, bazı çalışmalarda anti-diyabetik olarak kullanılan bazı ilaçların diyabetli bireylerde kardiyovasküler sistem sorunlarına ek sorunlar getirebildiğini de işaret etmektedir (25-31). Bu çalışmada, önceki çalışmamızda yüksek sükroz ile beslenerek MetS geliştiği kanıtlanmış ve sol ventrikül kasılma kuvvetinin baskılandığ gösterilmiş olan sıçanlar kullanılmıştır (32). Bu çalışmada ilk hedefimiz, bu hayvanlara insülin-duyarlaştırıcı pioglitazon uygulayarak kalp fonksiyonu üzerindeki etkileri incelemektir. İkinci hedefimiz, MetS-indüklü gelişen kalp fonksiyon bozukluğunun altında yatan nedenler arasinda artan oksidatif stres olup olmadiğını göstermek olup, ikinci bir grup MetS'lu hayvanlara bilinen bir antioksidan (kuersetin) uygulayarak, sonuçları karșılaștırmalı olarak incelemektir. Bu hedeflere ulaşmak için hem izole kalp ölçümleri ve hem de kalbin ventrikül kısmından taze olarak izole edilen kardiyomiyositlerde fonksiyonel çalışmalar gerçekleştirilmiştir.

\section{MATERYAL ve METODLAR}

\section{Sıçanlarda Metabolik Sendrom Olusturulması}

Çalışmamızda kullanılan deney hayvanları için Ankara Üniversitesi Hayvan Deneyleri Yerel Etik Kurulundan onay raporu alınmıştır (2012-5-35 ve 2015-10-125). Deneyler için, ağırlıkları 200-250 g arasında değişen, yaklaşık 3-aylık, Wistar türü erkek sıçanlar kullanılmıștır. Bu çalışmada dört farklı deney grubu kullanılmışır: Kontrol grubu (Kongrubu; normal diyet, standart sıçan yemi ve içme suyu ile beslenen s1çanlar, 18-hafta), metabolik sendrom grubu (MetS-grubu; normal diyetlerine ek olarak içme suyuna karıştırılan $935 \mathrm{mM}, \% 32$ sükroz ilave edilmiş su ile 18-hafta beslenen grup; (29)), MetS-gruba son 2hafta süre ile pioglitazon verilen grup (Piog-grubu; $30 \mathrm{mg} / \mathrm{kg} /$ gün, gavaj yoluyla) ve yine MetS-gruba son 2-hafta süre ile kuersetin (Kuer-grubu; $75 \mathrm{mg} / \mathrm{kg} /$ gün, gavaj yoluyla) verilen grup. Tüm hayvanlarının deney öncesi ve sonrası vücut ağırlıkları ve kan şekerleri ölçülmüştür.

\section{Sol Ventrikül İçi Basınç Ölçümü}

Heparinli pentobarbital $(30 \mathrm{mg} / \mathrm{kg}$ ) anestezisi altında kalpler hızlı bir şekilde çıkarılarak önceden gazlandırılmış $\left(\% 95 \mathrm{O}_{2}\right.$ ve $\% 5 \mathrm{CO}_{2}$ ile) KrebsHensleit çözeltisi [(mM olarak): $\mathrm{NaCl} 119 ; \mathrm{KCl} 4,8 ; \mathrm{CaCl}_{2}$ 1,8; $\mathrm{MgSO}_{4} 1,2 ; \mathrm{KH}_{2} \mathrm{PO}_{4} 1,2 ; \mathrm{NaHCO}_{3}$ 20; glukoz 10 ve $\mathrm{pH}: 7,4]$ içerisinde temizlenerek, Langendorff perfüzyon sistemine yerleştirilmiştir. Deney öncesi izole kalplerde atriyumlar alınarak ve atriyoventriküler nod ezilerek kalbin spontan aktivitesi engellenmiş, yalnızca dışarıdan uygulanan elektriksel uyarım ile tüm örneklerde aynı kalp atım hızı (uyar1 frekans1 300 atım/dakika) elde edilmiştir. İzole kalbin kasılma gücü, sol ventrikül içine yerleştirilen içi sıvı dolu bir balon ile basınç değișimleri olarak ölçülmüștür. Bu koşullar altında, kalplerin sol ventrikül içi basinç değerleri $200 \mathrm{~Hz}$ örnekleme hızıyla, bir basınç çevi- 
reci ve bir $\mathrm{A} / \mathrm{D}$ dönüştürücü yardımıyla kaydedilmiștir. Balon içinde uyarı ile oluşan basınç değişiklikleri, intraventriküler (sol ventrikül) izovolumetrik basınç değişikliklerini temsil etmektedir (SVBD).

\section{Kardiyomiyositlerin İzolasyonu}

Hafif anestezi altında $(30 \mathrm{mg} / \mathrm{kg}$ sodyum pentobarbital) kalpler hızlı bir şekilde çıkarılıp, soğuk ve $\mathrm{Ca}^{2+}$ 'suz fizyolojik bir çözelti içerisine konularak, kollajenaz $(1,2 \mathrm{mg} / \mathrm{mL})$ perfüzyonu ile hücre izolasyonu yapılmıştır. Langendorff düzeneği yardımiyla aorttan ters perfüzyon yöntemi ile önce içeriği; ( $\mathrm{mM}$ olarak) $\mathrm{NaCl} 130,5,4 \mathrm{KCl}, 1,4 \mathrm{MgCl}_{2}$, $0,4 \mathrm{NaH}_{2} \mathrm{PO}_{4}, 5$ HEPES, 10 glukoz ve 20 taurin, $\mathrm{pH} \mathrm{7,4}$ olan ve $\% 100 \mathrm{O}_{2}$ ile gazlandırılan, $\mathrm{Ca}^{2+}$ 'suz perfüzyon çözeltisi ile 5 -dk boyunca perfüze edildikten sonra, kollajenaz içeren çözelti ile yaklaşık 25$\mathrm{dk}$ boyunca perfüze edilmiștir. Perfüzyon süresinin bitiminde sistemden alınan kalp dokusu $\mathrm{Ca}^{2+}$ içermeyen perfüzyon solusyonu içerisine alınmış ve mekanik olarak küçük parçalara ayrılmıştır. Daha sonra, ince bir filtreden geçirilerek hücreler bir tüpün içerisine alınmış ve izole edilen hücreler $37^{\circ} \mathrm{C}^{\prime} \mathrm{de}$, çözeltideki son $\mathrm{Ca}^{2+}$ miktar1 $1,8 \mathrm{mM}$ olacak şekilde kademeli olarak 0,30,5-1,0 mM Ca ${ }^{2+}$ içeren çözelti ile yıkanarak ölü hücrelerden arınd1rılmış ve deneye hazır hale getirilmiştir.

\section{Hücre-içi Global Ca2+ Değișimleri- nin Ölçümü}

Hücre-içi serbest $\mathrm{Ca}^{2+}$ seviyesi $\left(\left[\mathrm{Ca}^{2+}\right]_{i}\right)$ ölçümlerinin yapılabilmesi için izole edilen kardiyomiyositler önce Fura2 AM $(4-\mu \mathrm{M})$ ile oda sicaklığında 45-dk süreyle inkübe edilerek boyanmış, ve mikrospektroflorometre kullanarak (340 nm ile $380 \mathrm{~nm}$ dalga boylarında uyarılarak ve $520 \mathrm{~nm}$ dalga boyunda emisyon toplanarak) tek hücrede $\left[\mathrm{Ca}^{2+}\right]_{\mathrm{i}}$ ölçümü floresans şiddetindeki değişim olarak ölçülmüştür (PTI RatioMaster). Bu $\left[\mathrm{Ca}^{2+}\right]_{i}$ ölçümlerinde kullanılan banyo çözeltisinin içeriği şu şekildedir: (mM olarak) $\mathrm{NaCl}$
130, $\mathrm{KCl} 4,8, \mathrm{MgSO}_{4}$ 1,2, $\mathrm{CaCl}_{2}$ $1,5, \mathrm{KH}_{2} \mathrm{PO}_{4} 1,2$, HEPES 10 ve glukoz $10(\mathrm{pH}=7,4)$. Floresans boya şiddetindeki değişim kullanılarak, hücrelerden önce 20-s'lik bazal $\mathrm{Ca}^{2+}$ sinyali kaydedilmiş, daha sonra aksiyon potansiyelini mimik etmek amaciyla elektrik alan uyarıs kullanılarak (25-30 V'luk tek yönlü kare-biçimli ve $0,2 \mathrm{~Hz}$ frekansında elektriksel uyarı) küvet içerisine alınan hücrelerden uyarılabilir olanı seçilerek ve bir pencere içine alınarak bu hücrelerde 200-s süre ile geçici (transient) $\left[\mathrm{Ca}^{2+}\right]_{\mathrm{i}}$ değișimleri kaydedilmiştir. Geçici $\left[\mathrm{Ca}^{2+}\right]_{i}$ değişimlerinin kinetik analizi Microsoft Excell programı ile hazırlanan bir analiz algoritması ile gama dağılım fonksiyonuna uydurularak gerçekleştirilmiştir. Serbest $\left[\mathrm{Ca}^{2+}\right]_{\mathrm{i}}$ seviyeleri ile ilgili floresans sinyallerinin bazal değerden çıkarılarak ölçülen tepe değeri [maksimum floresans şiddeti $\left.\left(\Delta \mathrm{F}_{340 / 380}\right)\right]$, tepeye çıkış süresi (TP) ve maksimum değerin \%50'sine iniş süresi $\left(\mathrm{DT}_{50}\right)$ ölçülerek, gruplar arasında karşılaştırılmalar yapılmıştır.

\section{MetS'lu Sıçanlarda Serum Oksidan ve Antioksidan Seviyelerinin Ölçülmesi}

Tüm sıçanlaın serumlarında "toplam antioksidan durum, TAS" ve "toplam oksidan durum, TOS" özel kolorimetrik kitleri kullanılarak ölçülmüștür (Rel Assay Diagnostic firmas1, RL0017 ve RL0024). TAS ölçümlerinde, vitamin $\mathrm{E}$ analoğu olarak bilinen bir antioksidan olan Trolox ile kalibrasyon amaciyla kullanılmıştır. TOS ölçümlerinde ise kalibrasyon hidrojen peroksit ile yapilmıştır. Ortamda bulunan oksidanlar, deney ortamına eklediğimiz ferröz iyon çelatör kompleksini ferrik iyon haline okside ederek, oluşan ferrik iyonlar deney ortaminda bulunan kromojen ile renkli bir bileșik olușturmaları sayesinde tespit edilmiştir. TAS ve TOS ölçümleri için, bir dizi kimyasal reaksiyon sonucunda oluşan renk yoğunluğu spektrofotometrik olarak ölçülerek örneklerdeki antioksidan veya oksidan molekül yoğunlukları hesaplanmıştır.

\section{İstatistiksel Analizler}

Tüm deney sonuçları ortalama ( \pm SEM) olarak verilmiştir. Ortalamalar arasındaki farkın istatistiksel olarak anlamlilık seviyesi ANOVA (tukeypost-hoc) testi kullanılarak belirlenmiștir. Tüm değerlendirmelerde, istatistiksel anlamlılik test değeri $(\mathrm{p}<0,05)$ seçilmiştir.

\section{BULGULAR}

\section{Pioglitazon veya Kuersetin Uygu- lamasının MetS'lu Sıçanlarda- ki Genel Etkileri}

Önceki çalışmamızda, deneysel olarak siçanlarda MetS oluşturmak için, $\% 32$ oranında sükroz içeren içme suyu kullanılmış olup, "Türkiye Endokrinoloji ve Metabolizma Derneği'nin Metabolik Sendrom Calıșma Grubu tarafindan 2009 y1linda yayınlanan faaliyet raporundaki kriterler tanıma dayanarak, bu hayvanlarda MetS'un oluștuğu en az 3 parametrenin (insülin direnci, glukoz intolerans1, hiperlipidemi, hiperinsulinemi ve hipertansiyon olgular1 gibi) varlığ1 ile gösterilmiştir (32). Yüksek sükrozla 18-hafta süre ile beslenen sıçanlarda (MetSgrubu) normal içme suyu ile beslenenlere (Kon-grubu) göre vücut ağırlıklarının ve kan glukoz değerlerinin daha yüksek olduğu $(p<0,05)$ gözlenmiştir (Şekil 1A ve B). Bu bulgular, daha önceki çalışmamızla ve diğer grupların bulguları ile uyumludur (29, 32-34). Pioglitazon veya kuersetin uygulaması bu artışları önleyerek, bu 2 grupta ölçülen değerlerin kontrol grubundan farklı olmadığ1 görülmüştür ( $\mathrm{p}>0,05)$.

Tüm grupların serum örneklerinde kolorimetrik kitler kullanılarak, toplam oksidan durumu, TOS ve toplam antioksidan durumu, TAS ölçülmüş ve gruplar arası karşılaştırma yapılmıştır. Şekil $1 C$ ve D'den görüldüğü gibi, MetS-grubunda Kongrubuna göre önemli derecede yüksek ölçülen TOS değerinin her iki uygulama sonunda da yüksek kaldığ1 gözlenmiştir. Buna karşılık, hem pioglitazon ve hem de kuersetin uygulamalar1 MetS-grubunda azal- 
A
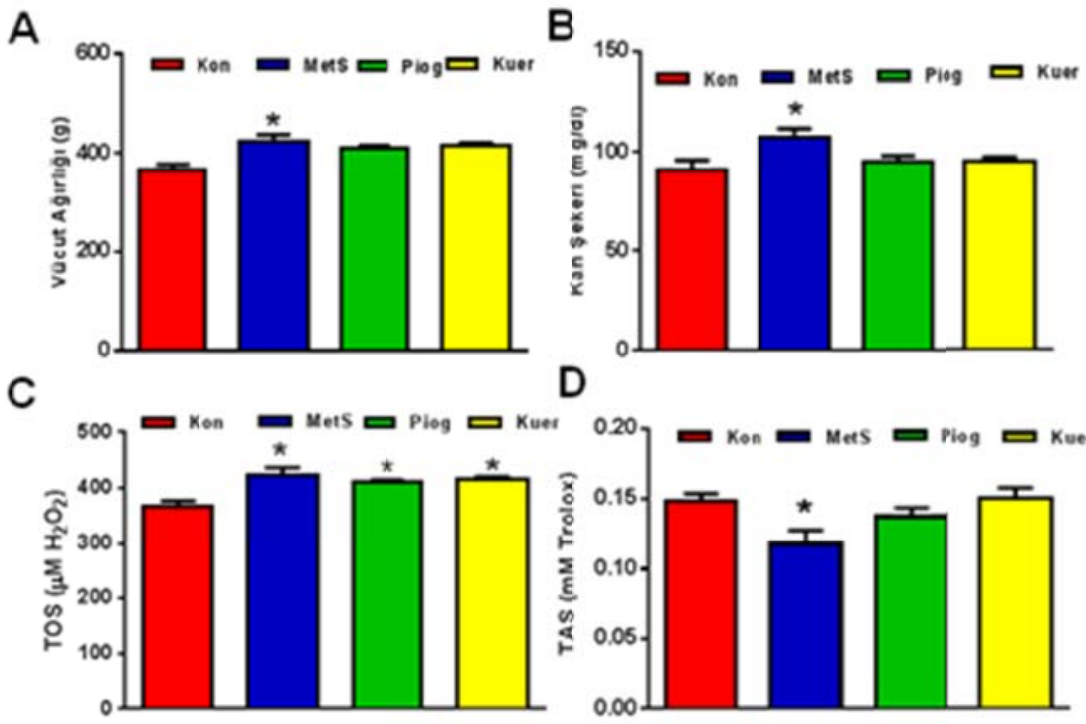

D

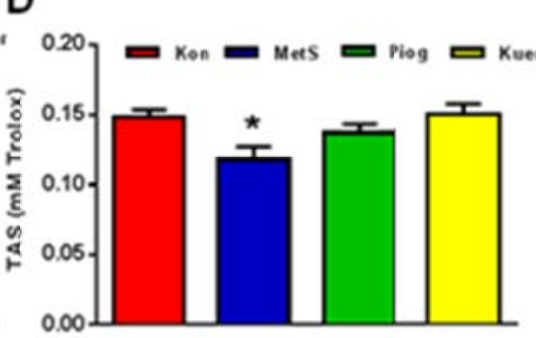

Şekil 1: Deney hayvanlarının genel parametreleri. (A) Vücut ağırlıkları, (B) kan glukoz seviyeleri, (C) serum toplam oksidan durumu TOS ve (D) toplam antioksidan durumu, TAS seviyeleri. Bar-grafikler ortalama \pm SEM değerleri olup, MetS-, pioglitazon- veya kuersetinuygulanmış MetS gruplarının (Piog ve Kuer) Kon-grubuna göre farklarının istatistiksel karşılaştırma seviyeleri ${ }^{\star} \mathrm{P}<0,05$ ile verilmiştir (her bir deney grubundan 7 hayvan örneği kullanılmıştır).

mış olan TAS değerini küçük fakat anlamlı şekilde normal değerlere doğru artmasina neden olmuştur $(\mathrm{p}<0,05)$.

Pioglitazon veya Kuersetin Uygulamasının MetS'lu Siçanlarda Kalbin Mekanik Aktivitesine Etkileri

Daha önceki çalışmamızda ayrıntılı olarak incelendiği gibi (32), bu grup çalışmamızda da, MetS-grubu siçanlarda sol ventriküliçi basınç değişimleri (SVBD) Langendorff-perfüzyon sisteminde ölçülmüştür. Bu grupta SVBD değerlerinin Kon-grubu ile karşılaştırıldığında önemli derecede azaldığ $(p<0,05)$, buna karşılık pioglitazon uygulaması bu azalmayı daha da dramatik hale getirirken, kuersetin uygulamasinin ise bu azalmayı engelleyemediği gözlenmiştir. Dört farklı sıçan grubuna ölçülen orijinal SVBD eğrileri görülmektedir (Şekil 2A). Bar grafikler ise ortalama olarak ölçülen maksimum SVBD değerlerini göstermektedir (Şekil 2B).
Pioglitazon veya Kuersetinin MetS'lu Siçanların İzole Kardiyomiyositlerinde Hücre-içi $\mathrm{Ca}^{2+}$ değişimlerine Etkileri

Sıçan kalbinden enzimatik yöntemle taze olarak izole edilen canlı kardiyomiyositler floresans boya ile boyanarak (Fura-2AM), tek hücre seviyesinde hücre-içi bazal serbest $\mathrm{Ca}^{2+}$ seviyeleri, $\left[\mathrm{Ca}^{2+}\right]_{\mathrm{i}}$ ölçülerek gruplar arası karşılaştırma yapılmıştır. Şekil 2C'de görüldüğü gibi ortalama olarak MetS-grubunda bu değerin Kon-grubuna göre önemli derecede yüksek $(\mathrm{p}<0,05)$ olduğu $\left(\mathrm{Ca}^{2+}\right.$. yüklenmesi) gözlenmiştir. MetSgrubuna hem pioglitazon uygulamas1 ve hem de kuersetin uygulama bu artışı engelleyerek, normal değerlere geri dönmesini sağlamıştır. Hücre seviyesinde yapılan çalışmalar, bu iki ajanın MetS-grubunda benzer etki yaparak, kardiyomiyositlerdeki $\mathrm{Ca}^{2+}$-artışını (overload) önledikleri gözlenmiştir $(\mathrm{p}<0,05)$.

Floresans boya ile boyanmış kardiyomiyositler elektrik alan uyarı altında birakılarak (aksiyon potansiyelinin mimik edilmesi), geçici (transients)
$\left[\mathrm{Ca}^{2+}\right]_{i}$-değişimleri ölçülmüş olup bu değişimlerin farklı parametreleri hesaplanarak gruplar arası karşılaştırmalar yapılmıstır. Şekil 3A'da farklı grup kardiyomiyositlerde elektrik alan altında mikrospektroflorometre ile ölçülen orijinal

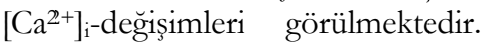
Ortalama olarak $\left[\mathrm{Ca}^{2+}\right]_{\mathrm{i}-}$ değişimlerinin maksimum değerleri MetS-grubunda Kon-grubuna göre azalırken $(\mathrm{p}<0,05)$, hem pioglitazon ve hem de kuersetin uygulamasinin bu azalmayı engelleyerek $(p<0,05)$, normal değerlere geri dönmesini sağlamıştır (Şekil 3B). Bu floresans değişimlerinin zaman deseni incelendiğinde, örneğin, fluoresansin maksimum değere yükselme süresinin MetS-grubunda Kon-grubuna göre çok belirgin şekilde yavaşlamış olduğu $(p<0,05)$, buna karşın her iki ajan uygulamasının bu uzamayı normal değerlere geri döndürdügü ( $<<0,05)$ gözlenmiştir (Şekil 3C). Bunlara ek olarak, floresansin maksimum değerden geriye azalma süresinin \%50'si ölçüldüğünde, bu sürenin MetS-grubunda Kongrubuna göre çok belirgin şekilde yavaşlamış olduğu $(p<0,05)$, buna karşin her iki ajan uygulamasının bu uzamayı engelleyebildiği fakat bu değissimin yine de normal değerlerin üzerinde olduğu $(\mathrm{p}<0,05)$ gözllenmiştir (Şekil 3D).

\section{TARTIȘMA}

Metabolik sendrom (MetS), genellikle obezite ve tip 2 diyabet hastalı̆g ile sonllanan, yüksek kan şekeri (hiperglisemi) düzeyi ve insülin direnci (hiperinsülinemi) ile karakterize ve yaşamımızı tehdit eden önemli bir metabolik hastalıktır. Yüksek sükroz ile elde edilen MetS'lu sıçanlarda, bazal kalp fonksiyonunun bozulduğu, örneğin sol ventrikül sistolik basıncı azalırken diyastolik basınç değerinin arttığı gözlenmiștir ve aritmi görülme olasılığının çok yüksek olduğu bildirilmiştir (9, 24, 32, 35). MetS-grubu sıçan kalbinde gözllenen mekanik ativitedeki bozulmanin/azalmanin altında yatan nedenler arasinda, önceki çalışmamızda gözlemiş olduğumuz 
kalp dokusundaki miyofibril kayıları ve organizasyon bozukluğu bulunduğunu düşündürmektedir (32). Kalp kasilma birimi olan miyofibrillerde gözlenen bu değişimler kalp kasılma gücünün azalmasının bir nedeni olarak değerlendirilebilir (36). MetS durumunda kalp doku örneklerinde gözlenen bağ doku birikimi ise dokunun elastik bileşenlerinde bozulmalar olduğunu göstermektedir ve bu değişimlerin kasılma-gevşeme süreçlerinde gözlediğimiz yavaşlamaya katk1 sağlad1ğını işaret etmektedir (37-42). Pioglitazon veya kuersetinin MetSgrubu sıçanlara uygulamanın bu parametreleri etkileyemediğini, bu nedenle sol ventrikül içi basınç değişimlerinde herhangi bir pozitif inotropik etkiye (organ seviyesinde) neden olamadıklarını düşündürmektedir. Yapılan bir klinik çalışmada, pioglitazon tip 2 diyabetli hastalarda 6-ay süre ile kullanılmış fakat kalp fonksiyonları üzerinde önemli pozitif etkiler göstermediği bildirilmiştir (43).

$\mathrm{Bu}$ bulgumuzu destekler nitelikte, NIH tarafindan (44) pioglitazonun diyabetli bireylerde ve diyabet ketoasidozda yararlı olmadığını ve hatta zararlı olduğunu işaret edilmiştir. Ayrıca, pioglitazonun sıvı tutulmasina ve periferik ödeme neden olabildiği ve sıvı-aşırı yüklenmesi ile konjektif kalp yetmezliğine yol açtığ1 da ileri sürülmektedir $(45,46)$. Ayrica, kuersetin uygulmasinın MetS-grubunda gözlenen mekanik aktivitedeki azalmada önemli bir düzelmeye neden olamadığı, buna karşllık TAS seviyesinde önemli derecede artışa neden olabilmesinin nedeni, kuersetin uygulamasinın daha uzun süreli kullanılmasinın gerekli olduğunu düşündürmektedir.

Diğer yandan, kontrol ve MetS gruplarindan izole edilen kardiyomiyositler elektriksel alan uyarımı ile uyarrldıklarında (aksiyon potansiyeli altında), hücre-içi bazal ve geçici $\mathrm{Ca}^{2+},\left[\mathrm{Ca}^{2+}\right]_{\mathrm{i}}$ değişimlerinin gruplar arasinda şiddet ve zaman deseni olarak farklılık gösterdiği ve hem pioglitazon hem de kuersetin uygu-
A

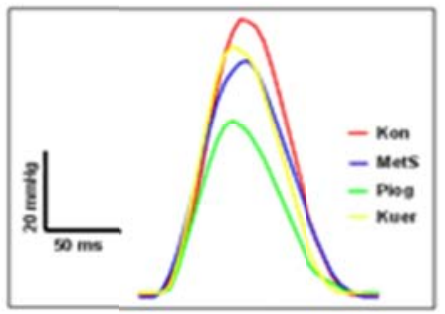

B

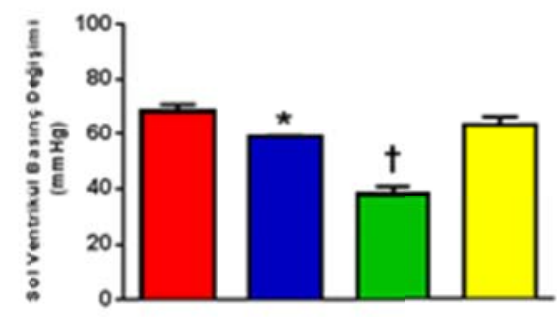

C

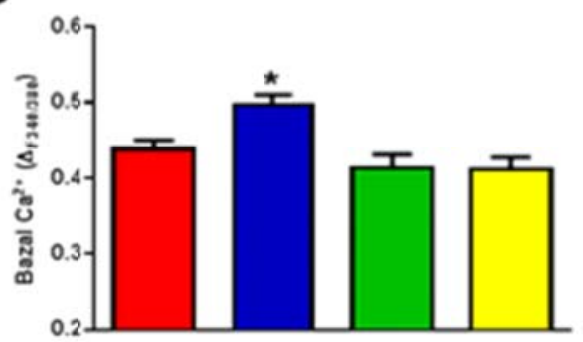

Şekil 2: İzovolumetrik olarak sol ventrikül içi basınç değişimlerinin (SVBD) in situ olarak incelenmesi. (A) Orijinal basınç değişim eğrileri, (B) bar-grafikler gruplar için SVBD değerlerinin ortalama \pm SEM değerlerini ve $(C)$ gruplar için izole ve Fura-2AM boyalı kardiyomiyositlerde ölçülen bazal serbest $\mathrm{Ca}^{2+}$ seviyelerinin $\left(\left[\mathrm{Ca}^{2+}\right]_{i}\right)$ ortalama \pm SEM değerlerini göstermektedir. Deney gruplarının Kon-grubuna göre farklarının istatistiksel karşılaştırma seviyeleri $P<0,05$ ile Piog-grubunun MetS-grubuna göre farkının istatistiksel karşılaştırma seviyesi $P<0,05$ ile verilmiştir (her bir deney grubundan 5 hayvan kalbi ile bu kalplerden izole edilmiş 10-15 hücre kullanılmıştır).
A

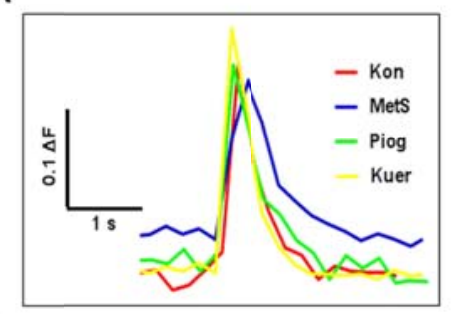

C

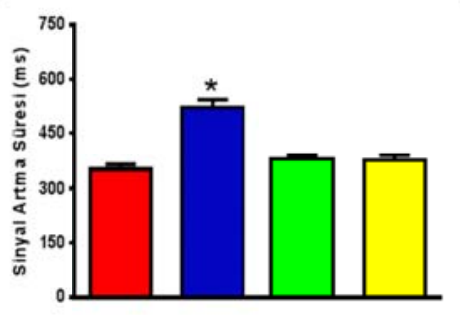

B

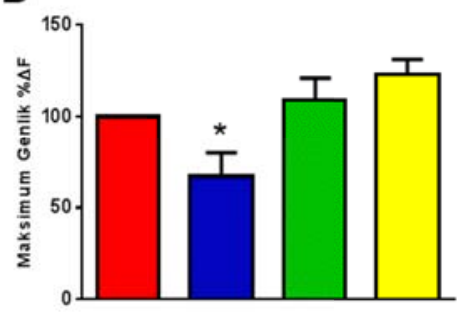

D

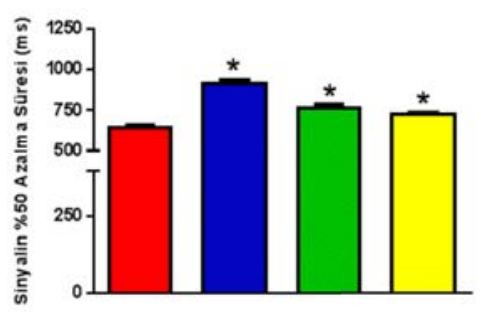

Şekil 3: İzole ve Fura-2AM ile boyalı kardiyomiyositlerde geçici hücre-içi serbest $\mathrm{Ca}^{2+},\left[\mathrm{Ca}^{2+}\right]_{\mathrm{i}}$ değişimleri. (A) Farklı gruplara ait kardiyomiyositler, elektriksel uyarı altında (aksiyon potansiyeli altında) uyarılarak (25-30 V'luk sinyal ille $0,2 \mathrm{~Hz}$ frekansında) ölçülen geçici floresan değişimlerine (geçici $\left[\mathrm{Ca}^{2+}\right]_{\mathrm{i}}$ ) ait orijinal örnek eğriler. Maksimum floresan şiddet değişimleri (B), floresansın maksimum değerine çıkış süreleri (C), ve floresansın maksiumum değerinden sönme/azalma değerinin \% 50"sine iniş süreleri (D) ortalama \pm SEM olarak verilmiştir. Deney gruplarının Kon-grubuna göre farklarının istatistiksel karşılaştırma seviyeleri $\mathrm{P}<0,05$ ile verilmiştir (her bir deney grubuna ait 5 hayvan kalbinden izole edilmiş 10-15 hücre kullanılmıştır). 
lamasının bu değişimleri tam olarak kontrol grubu değerlerine geri döndürdüğü gözlenmiştir. $\mathrm{Bu} 2$ ajan uygulaması, MetS indüklü değişen $\left[\mathrm{Ca}^{2+}\right]_{\mathrm{i}}$ ile ilgili mekanizmaları hücre seviyesinde pozitif yönde etkilediği gözlenmiştir. MetS’lu sıçan kardiyomiyositlerinde elektriksel uyarım ile gözlenen $\left[\mathrm{Ca}^{2+}\right]_{\text {i yanitla- }}$ rındaki bu değişim MetS'da gözlenen kalp fonksiyon bozukluğunun yapısal temelinin yanında işlevsel temele de dayandığını göstermektedir. $\mathrm{Bu}$ sonuçlar MetS deney modellerinde kaydedilen önceki veriler tarafindan desteklenmektedir (20, 24, 29, 31, 47, 48). Önceki çalışmalarda, yüksek sükroz içerikli diyet ile MetS deney modeli oluştu-

\section{KAYNAKLAR}

1. Reaven GM, Chang H, Hoffman BB. Additive hypoglycemic effects of drugs that modify free-fatty acid metabolism by different mechanisms in rats with streptozocin-induced diabetes. Diabetes 1988;37: 28-32.

2. Hanson RL, Imperatore G, Bennett PH, et al. Components of the "metabolic syndrome" and incidence of type 2 diabetes. Diabetes 2002;51: 3120-3127.

3. Meigs JB, Nathan DM, D'Agostino RB, Sr., Wilson PW, Framingham Offspring S. Fasting and postchallenge glycemia and cardiovascular disease risk: the Framingham Offspring Study. Diabetes Care 2002;25: 1845-1850.

4. Gundogan K, Bayram F, Capak M, et al. Prevalence of metabolic syndrome in the Mediterranean region of Turkey: evaluation of hypertension, diabetes mellitus, obesity, and dyslipidemia. Metab Syndr Relat Disord. 2009; 7: 427-434.

5. Demiral Y, Soysal A, Can Bilgin A, et al. The association of job strain with coronary heart disease and metabolic syndrome in municipal workers in Turkey. $\mathrm{J} \mathrm{Oc}$ cup Health 2006;48: 332-338.

6. Onat A, Yuksel M, Koroglu B, et al. [Turkish Adult Risk Factor Study survey 2012: overall and coronary mortality and trends in the prevalence of metabolic syndrome]. Turk Kardiyol Dern Ars 2013;41: 373-378.

7. Onat A. On the coronary heart disease mortality in Turkey. Atherosclerosis 2002;163: 203-204. rulan sıçanlarda ventriküler miyositlerin kisalma ve tekrar uzama evrelerinin kontrole göre (\%42-63) daha yavaş olduğu görülmüştür (47). Mellor ve ark. (48) 2012 yilında yayınladıkları çalışmada ise geçici $\left[\mathrm{Ca}^{2+}\right]_{\mathrm{i}}$ değişimlerinin şiddetinin kontrole göre $\% 42$ düştügünü, geçici $\left[\mathrm{Ca}^{2+}\right]_{i}$ fluoresans sönümlenme fazının zaman sabitinin ise \%24 oranında uzadığını göstermişlerdir. $\mathrm{Bu}$ bulgular bizim bulgularımızla uyumlu olup, kalbin mekanik aktivitesindeki MetS indüklü değişimleri açıklayabilmektedir. Hem pioglitazon hem de kuersetin uygulamalar1 bu parametreleri MetSgrubunda önemli derecelerde etkilemiştir.
Sonuç olarak bu çalışma, MetS-indüklü kalp fonksiyon bozukluğunda artan oksidatif stresin ve azalan antioksidan savunma sistemimin rol oynadığını, yeterli miktarlarda ve sürelerde antioksidan kullanılmasının MetS'lu bireylerde kalbin mekanik aktivitesi üzerinde koruyucu etkilere neden olabileceğini işaret etmektedir. Ayrıca, insülin-duyarlaştırıcı olarak kullanilan pioglitazonun güvenli bir şekilde MetS-grupta kullanılabilmesi için (klinik uygulamalar için) birçok farklı parametrelerin daha incelenmesinin gerekli olduğu bu çalışma sonuçları ile sergilenmek istenmiştir.
8. Soysal A, Demiral Y, Soysal D, et al. The prevalence of metabolic syndrome among young adults in Izmir, Turkey. Anadolu Kardiyol Derg 2005;5: 196-201.

9. Panchal SK, Poudyal H, Iyer A, et al. High-carbohydrate high-fat diet-induced metabolic syndrome and cardiovascular remodeling in rats. J Cardiovasc Pharmacol 2011;57: 51-64.

10. Davidoff AJ, Mason MM, Davidson MB, et al. Sucrose-induced cardiomyocyte dysfunction is both preventable and reversible with clinically relevant treatments. $A m \mathrm{~J}$ Physiol Endocrinol Metab 2004;286: E718724.

11. Fang ZY, Schull-Meade R, Downey M, et al. Determinants of subclinical diabetic heart disease. Diabetologia 2005;48: 394402.

12. de Freitas EV, Brandao AA, Pozzan R, et al. Study of the intima-media thickening in carotid arteries of healthy elderly with high blood pressure and elderly with high blood pressure and dyslipidemia. Clin Interv Aging 2008;3: 525-534.

13. Gonsolin D, Couturier K, Garait B, et al. High dietary sucrose triggers hyperinsulinemia, increases myocardial betaoxidation, reduces glycolytic flux and delays post-ischemic contractile recovery. Mol Cell Biochem 2007;295: 217-228.

14. Pang PS, Cleland JG, Teerlink JR, et al. A proposal to standardize dyspnoea measurement in clinical trials of acute heart failure syndromes: the need for a uniform approach. Eur Heart J 2008;29: 816-824.
15. Davidoff AW, Boyden PA, Schwartz K, et al. Congestive heart failure after myocardial infarction in the rat: cardiac force and spontaneous sarcomere activity. Ann N Y Acad Sci 2004;1015: 84-95.

16. Banos G, Medina-Campos ON, Maldonado PD, et al. Activities of antioxidant enzymes in two stages of pathology development in sucrose-fed rats. Can J Physiol Pharmacol 2005;83: 278-286.

17. Cardenas G, Carlos Torres J, Zamora J, et al. Isolated heart function after ischemia and reperfusion in sucrose-fed rats: influence of gender and treatment. Clin Exp Hypertens 2006;28: 85-107.

18. Perez-Torres I, El Hafidi M, Infante O, et al. Effects of sex hormone levels on aortic vascular reactivity and variables associated with the metabolic syndrome in sucrose-fed female rats. Can J Physiol Pharmacol 2008;86: 25-35.

19. Perricone NV, Bagchi D, Echard B, et al. Blood pressure lowering effects of niacinbound chromium(III) (NBC) in sucrosefed rats: renin-angiotensin system. J Inorg Biochem 2008;102: 1541-1548.

20. Ilkun O, Boudina S. Cardiac dysfunction and oxidative stress in the metabolic syndrome: an update on antioxidant therapies. Curr Pharm Des 2013;19: 48064817.

21. Whaley-Connell A, Sowers JR. Oxidative stress in the cardiorenal metabolic syndrome. Curr Hypertens Rep 2012;14: 360365. 
22. Strakovsky RS, Pan YX. In utero oxidative stress epigenetically programs antioxidant defense capacity and adulthood diseases. Antioxid Redox Signal 2012;17: 237 253.

23. Ren J, Pulakat L, Whaley-Connell A, Sowers JR. Mitochondrial biogenesis in the metabolic syndrome and cardiovascular disease. J Mol Med (Berl) 2010;88: 993 1001.

24. Roberts CK, Barnard RJ, Sindhu RK, et al. Oxidative stress and dysregulation of $\mathrm{NAD}(\mathrm{P}) \mathrm{H}$ oxidase and antioxidant enzymes in diet-induced metabolic syndrome. Metabolism 2006;55: 928-934.

25. Abbas A, Milles J, Ramachandran S. Rosuvastatin and atorvastatin: comparative effects on glucose metabolism in nondiabetic patients with dyslipidaemia. Clin Med Insights Endocrinol Diabetes 2012;5: 13-30.

26. Hemmeryckx B, Hoylaerts MF, Gallacher DJ, et al. Does rosiglitazone affect adiposity and cardiac function in genetic diabetic mice? Eur J Pharmacol 2013;700: 23-31.

27. Thackeray JT, deKemp RA, Beanlands RS, et al. Early diabetes treatment does not prevent sympathetic dysinnervation in the streptozotocin diabetic rat heart. $J$ Nucl Cardiol 2014;21: 829-841.

28. Yilmaz M, Bukan N, Demirci $H$, et al. Serum resistin and adiponectin levels in women with polycystic ovary syndrome. Gynecol EndocrinoL 2009;25: 246-252.

29. Vasanji Z, Cantor EJ, Juric D, et al. Alterations in cardiac contractile performance and sarcoplasmic reticulum function in sucrose-fed rats is associated with insulin resistance. Am I Physiol Cell Physiol 2006;291: C772-780.

30. Breunig IM, Shaya FT, McPherson ML, et al. Development of heart failure in Medicaid patients with type 2 diabetes treated with pioglitazone, rosiglitazone, or metformin. I Manag Care Spec Pharm 2014;20: 895-903.
31. Palee S, Chattipakorn S, Phrommintikul A, et al. PPARgamma activator, rosiglitazone: Is it beneficial or harmful to the cardiovascular system? World J Cardiol 2011;3: 144-152.

32. Okatan EN, Kizil S, Gokturk H, et al. High-carbohydrate diet-induced myocardial remodelling in rats. Curr Res Cardiol 2015; 2(1):5-10.

33 Balderas-Villalobos J, Molina-Munoz T, Mailloux-Salinas P, et al. Oxidative stress in cardiomyocytes contributes to decreased SERCA2a activity in rats with metabolic syndrome. Am J Physiol Heart Circ Physiol 2013;305: H1344-1353.

34. Aguilera AA, Diaz GH, Barcelata ML, et al. Effects of fish oil on hypertension, plasma lipids, and tumor necrosis factoralpha in rats with sucrose-induced metabolic syndrome. I Nutr Biochem 2004;15: 350-357.

35. Dutta K, Podolin DA, Davidson MB, et al. Cardiomyocyte dysfunction in sucrosefed rats is associated with insulin resistance. Diabetes 2001;50: 1186-1192.

36. Jalil JE, Doering CW, Janicki JS, et al. Fibrillar collagen and myocardial stiffness in the intact hypertrophied rat left ventricle. Circ Res 1989;64: 1041-1050.

37. Heerkens YF, Woittiez RD, Kiela J, et al. Mechanical properties of passive rat muscle during sinusoidal stretching. Pflugers Arch 1987;409: 438-447.

38. Nikolic S, Yellin EL, Tamura $K$, et al. Passive properties of canine left ventricle: diastolic stiffness and restoring forces. Circ Res 1988;62: 1210-1222.

39. Thiedemann KU, Holubarsch C, Medugorac I, et al. Connective tissue content and myocardial stiffness in pressure overload hypertrophy. A combined study of morphologic, morphometric, biochemical, and mechanical parameters. Basic Res Cardiol 1983;78: 140-155.

40. Riva E, Andreoni G, Bianchi R, et al. Changes in diastolic function and colla- gen content in normotensive and hypertensive rats with long-term streptozotocin-induced diabetes. Pharmacol Res 1998;37: 233-240.

41. Regan TJ, Wu CF, Yeh CK, at al. Myocardial composition and function in diabetes. The effects of chronic insulin use. Circ Res 1981;49: 1268-1277.

42. Burlew BS, Weber KT. Connective tissue and the heart. Functional significance and regulatory mechanisms. Cardiol Clin 2000;18: 435-442.

43. Dorkhan M, Dencker M, Stagmo M, et al. Effect of pioglitazone versus insulin glargine on cardiac size, function, and measures of fluid retention in patients with type 2 diabetes. Cardiovasc Diabetol 2009;8: 15.

44, U.S. National Library of Medicine. "ACTOS (pioglitazone hydrochloride) tablet". NationalInstitutes of Health. 2010.

45. Berria R, Gastaldelli A, Lucidi S, et al. Reduction in hematocrit level after pioglitazone treatment is correlated with decreased plasma free testosterone level, not hemodilution, in women with polycystic ovary syndrome. Clin Pharmacol Ther 2006;80: 105-114.

46. Nissen SE, Nicholls SJ, Wolski K, et al Comparison of pioglitazone vs glimepiride on progression of coronary atherosclerosis in patients with type 2 diabetes: the PERISCOPE randomized controlled trial. Jama 2008;299: 1561-1573.

47. Miklos Z, Kemecsei P, Biro T, et al Early cardiac dysfunction is rescued by upregulation of SERCA2a pump activity in a rat model of metabolic syndrome. Acta Physiol (Oxf) 2012;205: 381-393.

48. Mellor KM, Wendt IR, Ritchie RH, et al. Fructose diet treatment in mice induces fundamental disturbance of cardiomyocyte $\mathrm{Ca} 2+$ handling and myofilament responsiveness. Am J Physiol Heart Circ Physiol 2012;302: H964-972 
